\title{
Does Fixed Assets Revaluation Create Avenues for Financial Numbers Game? Evidence from a Developing Country
}

\author{
Md. Tahidur RAHMAN ${ }^{1}$, Syed Zabid HOSSAIN ${ }^{2}$
}

Received: June 20, 2020 Revised: July 05, 2020 Accepted: August 10, 2020

\begin{abstract}
The study reveals the extent of changes in selective financial numbers caused by fixed asset revaluation (FAR) and explores whether there was a management motive for playing the financial numbers game through using the FAR model. The data set consists of a sample of 142 listed companies purposively selected from 13 industries. The study found a significant impact of FAR on the net asset value (NAV), fixed asset intensity (FAI), and debt-to-equity ratio (DER). These findings are supported by the political cost and the debt covenant hypotheses. The study also observed a high growth of fixed assets by $9.5 \%$ to $14,603.8 \%$ resulting from FAR. More revealing is that FAR increased NAV in revaluer companies by an average of $427.20 \%$ as compared to $6.86 \%$ in non-revaluer companies. Even some companies with negative NAV took resort on FAR to show positive NAV. Besides, revaluer companies managed to reduce their DER by $70.45 \%$ as opposed to an increase of $8.45 \%$ in non-revaluer companies. Hence, the study concludes that most of the publicly-listed companies are involved in financial numbers game by the use of the FAR model. To build confidence among investors, companies should practice FAR rightly and disclose related information to help reduce information asymmetry.
\end{abstract}

Keywords: Fixed Asset Revaluation, Financial Numbers Game, IAS 16, Value Relevance, International Valuation Standards

JEL Classification Code: G11, G12, G18, M41

\section{Introduction}

The historical cost has been the dominant practice for reporting fixed assets in the balance sheet in both developing and developed countries. From the viewpoint of verifiability, it is considered practical and objective (Herrmann, Saudagaran, \& Thomas, 2005; Khalil, Asad, \& Khan, 2018). But the main argument against historical cost is that it lacks relevance and helps conceal information about the financial health of a company, leading to market inefficiency (Bae, Lee, \& Kim, 2019; Poerwati, Hardiningsih, Srimindarti, $\&$ Sundari, 2020). The fair value of corporate fixed assets

${ }^{1}$ First and Corresponding Author. Associate Professor, Department of Business Administration, Bangladesh Army International University of Science and Technology, Bangladesh [Postal Address: Cumilla, 3501, Bangladesh] E-mail: towhidais@gmail.com

2Professor, Department of Accounting and Information Systems, University of Rajshahi, Bangladesh. E-mail: syed6205@ru.ac.bd

() Copyright: The Author(s)

This is an Open Access article distributed under the terms of the Creative Commons Attribution Non-Commercial License (https://creativecommons.org/licenses/by-nc/4.0/) which permits unrestricted non-commercial use, distribution, and reproduction in any medium, provided the original work is properly cited. change, either increase or decrease, due to inflation, utilization, passing of time, technological development, and some other reasons. Thus, fixed asset revaluation (FAR), a formal process of updating the carrying values of fixed assets to their fair values, is essential for the trustworthy presentation of assets owned by companies (Yoo, Choi, \& Pae, 2018; Bae et al., 2019; Sellhorn \& Stie, 2019). The fair value of an asset is considered more relevant to the users, and thus helps achieve two primary objectives of financial statements, namely, informativeness to stakeholders and stewardship of managers (Ronen, 2008; Barac \& Sodan, 2011; Seng \& Su, 2011; Sellhorn \& Stie, 2019). However, upward FAR is considered one of the most controversial issues among accounting practitioners, standard setters, investors, and academics.

Proponents argue that, besides minimizing information asymmetries and opportunistic behavior, FAR helps combat the problem of equity depletion, makes the terms of borrowing favorable, discovers the actual rate of return, assists investment decisions, communicates performance expectations, and also helps evade hostile takeovers caused by undervalued assets (Brown, Izan, \& Loh, 1992; Aboody, Barth, \& Kasznik, 1999; Wang, 2006; Pae, Park, \& Song, 
2010; Zakaria, Edwards, Holt, \& Ramchandran, 2014; Wali, 2015; Sellhorn \& Stie, 2019; Rafay, Yasser, \& Khalid, 2019). They also argue that FAR shows the current values of assets that indicates transparency, helps investors predict future firm performance (FFP), and takes sensible investment decisions (Palea, 2014; Sellhorn \& Stie, 2019).

Opponents argue that upward FAR being highly subjective and unreliable allows managers to play financial numbers game by reporting arbitrary accounting figures. Thus, it should not be allowed because of the possibility to shake investors' confidence in financial reporting (Wang, 2006; Hitz, 2007; Barac \& Sodan, 2011). Hitz (2007) has termed fair value as a synthetic value because it lacks verifiability that consequently creates a question about reliability. According to Mulford and Comiskey (2005), financial numbers games occur when managers, the key players of the games, try to fulfill their desired outcomes by altering the impressions of financial statement users (mainly investors and lenders) about financial performances and conditions of concerned companies. Moreover, the application of fair value in emerging markets is susceptible to produce unreliable information and noise in the market due to improper compliance with revaluation regulations (Mohammadrezaei, Mohd-Saleh, \& Banimahd, 2015; Sellhorn \& Stie, 2019; Dudycz \& Praźników, 2020).

However, FAR is considered suitable, even inevitable, in some special situations such as mergers, acquisitions, preparing for IPOs, and settling shareholders' disputes (Song $\&$ Pae, 2019). Any revaluation that results in the value of PP \& E exceeding the book value to a significant extent abates two leading risks, namely bankruptcy and delisting from the stock exchange. Besides, the high growth of fixed assets through revaluation indicates that the level of information asymmetry about PP\&E is high, which could be reduced by the disclosure of FAR (Song \& Pae, 2019).

FAR requires an accounting entry that has no direct impact on the cash inflows of a firm, but the cost of performing and recording the revaluation (Brown et al., 1992; Kang \& Paik, 2020). Revaluation increases are directly added to the equity, whereas decreases arising from revaluation transferred to the income statement. Hence, the practice of FAR, in no way, accelerates reported current income, but it reduces reported earnings if an asset is revalued downward or through an increased amount of depreciation arising from the upward revaluation of the asset (Yoo et al., 2018). However, the effect of FAR is evident in the financial statements through the accounting cycle, and thus, the disclosure relating to FAR is assumed to provide decision-useful information to the users (Hitz, 2007; Kovacs, 2013; Sellhorn \& Stie, 2019).

Despite many debates and suspicions about the fairness and application of FAR mentioned by Majercakova and Skoda (2015), Rahman (2017), Rahman et al. (2017), and others, many listed companies in Bangladesh have undertaken FAR as an option delineated in IAS 16. An item of PP\&E, as mandated in IAS 16, shall initially be recorded at its cost price; later on, companies can choose either the cost model or the revaluation model to report such assets (IAS, 2005). As fixed tangible assets generally consist of a large share of a firm's total assets, the selection of valuation method influences the figures in financial statements to a significant extent (Ballas, Panagiotoub, \& Tzovasc, 2014).

In Bangladesh, only a few companies revalued their fixed assets before the adoption of IAS 16 with effect from January 01, 2007. FAR started spreading after 2007, achieved momentum since 2009 , and hit the highest point in 2010. Meanwhile, the stock market of Bangladesh observed a devastating crash during 2010-11. Consequently, a probe committee was formed to investigate the factors responsible for the market crash. The committee showed that FAR is one of the reasons behind the formation of a stock market bubble and its subsequent bust (Khaled, 2011). The studies by Alam (2014), Hasan, Rahman, \& Hossain (2014), and Rahman, Hossain, \& Habibullah, (2017) also mentioned FAR was responsible for the crash. But none of these studies could uncover the magnitude of the effects on financial figures, or whether any numbers game played through FAR.

Although there are many studies, mostly in developed market economies, the findings from a developing country context may be different. The characteristics of the Bangladesh stock market are distinct in terms of regulatory setting, market environment, saving-investment culture, and the accounting value system. For example, investors in the Bangladesh stock market are mostly small who do not have basic knowledge of the stock market. They trade shares based on rumors or following the trends of big investors. Hence, deceiving investors or playing the numbers game is comparatively easy in the market. Therefore, investors, analysts, regulators, and academics might have a high interest in the financial numbers games using the FAR model.

In the above context, the study aims to answer the questions, such as: What are the magnitudes of changes in financial numbers caused by FAR practice? Do the changes help create an environment for playing financial number games? Do companies practice FAR for reporting the fair value of fixed assets, or they have any hidden motives? Answering these questions requires a thorough investigation of corporate FAR. Hence, the specific objective of this study is to demonstrate the extent of changes in selective financial numbers caused by FAR, and also to examine whether there was any management motive to play financial numbers games by applying the FAR model. The remaining parts of this paper are organized as follows: Section 2 explains the context of FAR practice in Bangladesh; Section 3 reviews the relevant literature and develops the hypothesis; Section 4 states the methodology used; Section 5 analyzes the data and explains the results, and Section 6 concludes the study. 


\section{The Context of FAR in Bangladesh}

Previous studies, such as Khaled (2011), Hasan et al. (2014), and Rahman (2017), pointed to FAR as one of the causes behind the 2010-11 stock market crash in Bangladesh. Hence, knowing stock market regulations is necessary to recognize the context of FAR in the country. Since Bangladesh has no distinct national accounting standards for professional accounting practices, it adopts International Accounting Standards (IASs) and International Financial Reporting Standards (IFRSs). Consequently, IAS 16 has been the main instrument guiding the accounting treatment of PP\&E (Property, plant, and equipment) and also for FAR. Before the 2010-11 stock market crash, any national guideline concerning FAR was absent in Bangladesh. Besides, the International Valuation Standards (IVS) concerning FAR were not mandatory for companies. All of these direct companies to practice FAR arbitrarily. After the crash, the Bangladesh Securities and Exchange Commission (BSEC) felt the necessity of detailed guidelines for FAR in the country. So, BSEC issued FAR guidelines on August 18, 2013, and made it obligatory for publicly listed companies willing to have their assets revalued (BSEC, 2013). According to the guidelines, listed companies intend to revalue their assets are to follow the applicable provisions of IVS. Thus, along with the BSEC Notification on Asset revaluation, IAS 16 and IVS are the principal instruments guiding FAR in Bangladesh.

The Bangladesh stock market is inefficient, where trades depend on rumors and speculations, small investors lack fundamental knowledge of the stock trading, regulatory control is weak, there are a few institutional investors. The market is also an occasional avenue for speculative foreign investors. Similar to some other Asian countries, information cascade, the tendency of following the lead of other investors in the condition of information asymmetry, is another characteristic of the Bangladesh Stock Market (Hong, 2016). The market, during its life of about sixty years, has experienced two devastating crashes. The first one occurred in 1996 and the most devastating latest one in 2010-11. The nightmare of the last stock market crash of 2010-11 has raised the anxiety of investors about a future market crash. In such an awful situation, diversifying portfolios cannot be the only solution. Regulators, investors, and other related parties must know the causes of bubbles and their subsequent busts that may help maintain a healthy stock market environment (Bae et al., 2019). A market reacts to FAR disclosure depending on the efficiency of the concerned market. If the market is inefficient, it inspires investors to respond irrationally to FAR disclosures (Penman, 2007; Bae et al., 2019). As the stock market in Bangladesh is inefficient, the practice of FAR raises concern among stakeholders. In this context, the finding of this study on FAR practices might be valuable to concerned parties.

\section{Literature Review and Hypothesis Development}

The debate among investors, corporate managers, standard setters, regulatory watchdogs, and academics about the superiority between the revaluation model and the historical cost model has been a hot topic (Christensen \& Nikolaev, 2013). Nonetheless, FAR has been a common practice for years in many developed countries with a strong capital market side by side in some developing and underdeveloped countries like Bangladesh. However, upward FAR is not permitted in some developed countries like the USA, Canada, Japan, and Germany (Easton, Eddey, \& Harris, 1993; Sayce \& Connellan, 2002; Seng \& Su, 2011).

\subsection{Accounting Theories and FAR}

A good number of studies have been conducted on FAR in different countries around the world covering issues, like the motivation behind FAR, corporate attributes influencing FAR, the timing and effect of FAR, and so forth. Most of the studies on FAR are managed by the Positive accounting theory (PAT), which implies that materialistic self-interest is the basis of every economic activity and, thus, it influences the selection of accounting methods and policies (Gaffikin, 2007). To explain the motives behind FAR, researchers such as Gaeremynck and Veugelers (1999), Godfrey, Hodgson, and Scott (2000), Jaggi and Tusi (2001), Gaffikin (2007), Chainirun and Narktabtee (2009), Lopes and Walker (2012), Christensen and Nikolaev (2013), Yao, Percy, and $\mathrm{Hu}$ (2015), Baek and Lee (2016), Jefriyanto and Mulya (2019), and others have applied one or more of the three hypotheses of PAT, namely, the Debt covenant hypothesis, the Signaling hypothesis, and the Political cost hypothesis. On the other hand, Ronen (2008), Abdel-Khalik (2010), Madison (2014), and Palea (2014) are among others who explained FAR decisions based on the Stewardship theory. They noted that the management plays numbers game by using FAR to establish their stewardship. Another group of researchers, such as Zakaria et al. (2014), Yao et al. (2015), Bae et al. (2019), Jefriyanto and Mulya (2019), Sellhorn and Stie (2019), and Song and Pae (2019) are among others who explained the motives behind FAR based on the Agency theory that implies self-interest is the principal driver behind the managerial performance and, thus, the choice of the FAR model.

\subsection{Revaluation Decision and FAR Motives}

Although the officially declared primary purpose of FAR is to present the real picture of fixed assets in the balance sheet, researchers have found diverse hidden motives behind the choice of FAR. Easton et al. (1993) found that the urge 
for FAR is to reduce the DER in Australia. Aboody et al. (1999) found observed that the desire for FAR is to signal better FFP estimated by income and operating cash inflows. Cheng and Lin (1999) affirmed that the motive behind FAR is to reduce high political costs, debt contracting costs, and information asymmetry problems. Missonier-Piera (2007) observed that FAR is to improve creditors' perception of the economic strength of corporate entities and thereby increase their borrowing limits. Chainirun and Narktabtee (2009) opined that the motive behind FAR is to signal investors about the status, growth opportunities, FFP, and liquidity of a company. Seng and $\mathrm{Su}(2010)$ noted the desire is to reduce high political costs. Barac and Sodan (2011) found FAR as a trick to improve the borrowing capability of companies, and thus reduce borrowing costs in Croatia. Iatridis and Kilirgiotis (2012) revealed that firms usually practice FAR to have the highest favorable financial outcomes by managers. Lopes and Walker (2012) found an improvement in equity position as the FAR motive. Zakaria et al. (2014) unveiled the following reasons: enhance performancedriven financial benefits, reduce debt costs, diminish high political costs, reduce information asymmetry, offer value relevance, and signal investors. Hu, Percy, and Yao (2015) found a positive association between earnings management and FAR decisions in Australian companies. The Iranian study of Jamshidian and Sharifabadi (2016) identified FAR as a technique of capital enhancement. Baek and Lee (2016) found that South Korean companies reduced debt costs after revaluation. The Malaysian study of Khalil, Asad, and Khan (2018) discovered the primary motive of FAR is to raise more funds by satisfying investors.

\subsection{Entity-Specific Factors and FAR}

To investigate entity-specific factors that influence FAR decisions, researchers have found several elements that are sometimes conflicting. Brown et al. (1992) explored that the high debt-to-asset ratio (DAR), the greater value of fixed asset intensity, and a low amount of reserve and surplus were the influential factors behind FAR. Cotter and Zimmer (1999) found that companies that encounter a declining trend of operating cash flows and an increasing trend of secured debt perform FAR in Australia. Based on a sample of 35 countries, Barlev, Fried, Hadda, and Livna (2007) found that leverage, liquidity, financing sources, financing requirements, capital intensity, capital expenditures, MBR, ROA, Size, and frequency of previous revaluations influence FAR decisions in different country regions. Unlike previous studies, they found no relationship between future cash flows and market returns with revaluation. Missonier-Piera (2007) explored a new factor, high export sales, associated with upward FAR. Barac and Sodan (2011) found that large and profitable companies with low liquidity, poor cash flow, and increased debt perform upward FAR. Iatardis and Kilirgiotis (2012), alike Seng and Su (2011), found firm size positively related to FAR. The study also found that firms with foreign operations, low intensity of fixed assets, and high needs for debt capital, are more likely to perform FAR. Lopes and Walker (2012) found a positive association between FAR, indebtedness, and liquidity in Brazil. The study discovered that FAR was negatively related to the corporate governance index, FFP, prices, and returns. Tabari and Adi (2014) found a significant relationship of FAR with DAR, operating cash flow, total assets, and the intensity of fixed assets of the companies before revaluation. Baek and Lee (2016) found a positive relationship between higher equity cost and leverage, and a negative relationship of profitability, cash flow, and Tobin's Q with FAR in South Korean companies. Nijam (2018) found that companies with a high share of land and building and financial leverage apply the revaluation model. The study did not find any effect of firm size, return-on-asset (ROA), and return-on-equity (ROE) on the choice of the revaluation model. Based on ten years' data, the Pakistani study of Rafay et al. (2019) found large (size) companies with high intensity of fixed assets and a low percentage of stock dividends are more induced to regular revaluation. Jefriyanto and Mulya (2019) found in the context of the Indonesian market that the size and intensity of fixed assets are positively related to FAR. But the study found an insignificant effect of leverage and liquidity. However, another Indonesian study by Poerwati et al. (2020) found no influence of size on FAR decisions, though they got a significant effect of fixed asset intensity (FAI) and operating cash flow on FAR. In summary, the factors and situations that might affect revaluation decision identified in the literature include issuing bonus shares, threats of a takeover, tougher lending agreements, exhausted borrowing capacity, declining cash flows, growth prospect, fixed assets' intensity, previous revaluation pattern, exhaustion of equity reserves, industry category, indebtedness, liquidity, company size, foreign sales, and so forth.

\subsection{Future Firm Performance (FFP) and FAR}

Beyond the common spectrum, some researchers have investigated the effects of asset revaluation on FFP. The study of Aboody et al. (1999) found a significant positive relationship between FAR and FFP expressed by operating income and cash flows from operations in the UK. This relationship was comparatively weak in highly leveraged firms. Similarly, Jaggi and Tusi (2001) observed that FAR was positively related to FFP in Hong Kong. Barlev et al. (2007), in their multi-country study, also found that FAR was positively related to FFP, but the degree of the relationship was very poor on an overall basis. In contrast, Lopes and Walker (2012) found that FAR was negatively related to FFP 
and corporate governance index. Using panel data of five years, Jamshidian and Sharifabadi (2016) found a significant positive association between capital increased through FAR and FFP expressed by operating profit and cash flows. The study by Azmi and Ali (2019) investigated the future effects of FAR and found positive effects on operating income but no significant effect on cash flow in Indonesia. The study conducted by Abbas, Fazal, Ali, and Faisal (2019) merely on the cement sector in Pakistan found a significant negative impact of FAR on FFP. In the South Korean study, Bae et al. (2019) investigated the relationship between FAR and stock price crash risk. The study concludes that FAR improves the timeliness and relevance of information, which ultimately reduces stock price crash risk, and helps to develop a sustainable market. Another South Korean study by Kang and Paik (2020) attempted to explore the cost and benefits of FAR by using natural experiments.

\subsection{Studies on FAR in Bangladesh}

In Bangladesh, our search on the Internet has found a dearth of literature on FAR. However, a few studies, such as Khaled (2011), Alam (2012), Alam (2014), Hasan et al. (2014), and Rahman (2017), have found irregularities and weaknesses in FAR practices. These studies conducted after the cruel stock market crash of Bangladesh in 2010-11. The report of Khalid (2011) prepared as a consequence of governmental investigation concerning the 2010-11 stock market crash. Stated some irregularities of FAR practices in Bangladesh, the report mentioned that FAR was one of the leading causes of the stock market collapse. Similar to Khalid (2011), the study of Alam (2012) and Hasan et al. (2014) mentioned that corrupt FAR practice was one of the reasons behind the crash. However, they did not conduct in-depth investigations to validate their statements. Alam (2014) conducted his research on non-financial companies to know the trend and status ofFAR practices in Bangladesh and observed that FAR was unpopular at that time. Rahman (2017) studied FAR practices before IPOs only in the Textile sector. By applying the regression model, the study found a negative relationship between FAR and fixed asset intensity. The study also witnessed that FAR is a practice for IPO companies in Bangladesh, with around 73\% of newly listed companies applied FAR before IPOs. All these imply that there is ample scope for intensive studies on FAR in the context of Bangladesh. This literature gap inspired us to explore the impacts of the FAR model on financial numbers attractive to most of the users.

\subsection{Hypothesis regarding FAR and Financial Numbers Game}

Like many other countries in the world, FAR is a voluntary accounting practice in Bangladesh. The main argument behind FAR is to show the fair value of fixed assets in the balance sheets of the respective companies (Tay, 2009). Cotter and Zimmer (2003) stated that managers are more interested to recognize and disclose FAR information when they think revaluation estimates more reliable. However, companies can increase the volume of assets and shareholders' equity through upward FAR, which ultimately reduces DER and also the debt costs of concerned companies (Lopes \& Walker, 2012; Baek \& Lee, 2016; Kang \& Paik, 2020). According to the Debt covenant hypothesis, companies can reduce DER by practicing FAR to reduce debt costs and make loan sections easier.

Although FAR has no direct effect on the current year's cash flow, it helps companies meet working capital needs by easing loan arrangements and reducing borrowing costs, which may positively influence future net profit after tax (NPAT) and net operating cash flow (NOCF). This argument is supported by Azmi and Ali (2019), who found a positive impact of FAR on future operating income. However, investors and lenders are more interested in NPAT and NOCF of concerned companies (Lee, Lee, Choi, \& Kim, 2020; Nguyen \& Nguyen, 2020).

Any growth of fixed assets caused by FAR radically changes the net asset value (NAV) and the fixed asset intensity (FAI). NAV per share is a significant consideration for investors in Bangladesh. Prudent investors critically evaluate NAV before purchasing stocks/shares. On the other hand, lending institutions closely monitor FAI to examine loan applications. Therefore, companies with negative or low NAV take resort to FAR for uplifting their conditions. If the managerial motive is to play the numbers game, FAR must enhance both NAV and FAI to a significant extent.

Researchers such as Brown et al. (1992), Seng and $\mathrm{Su}$ (2010), Iatridis and Kilirgiotis (2012), Azmi and Ali (2019), and others argued that FAR signals the growth potential of companies to investors. Conversely, some others argued that FAR provides a 'costly signal' for the future because of its adverse effect on ROA and ROE caused by increased assets and depreciation on assets. However, the market-to-book ratio (MBR) is considered as a routine measure of growth potentiality and is used to recognize whether a stock is undervalued or overvalued (Whittered and Chan, 1992; Lin and Peasnell, 2000; Barlev et al., 2007; Tay, 2009). Thus, companies with higher MBR are expected to have a high chance of using FAR. In connection with the MBR, FAR can be an instrument of playing numbers games for opportunistic managers. Based on the above inferences, we formulate six separate hypotheses. However, combining all together, we set those in the alternative form:

H1: There is a significant difference in NAV, NOCF, NPAT, DER, FAI, and MBR between the periods before and after the revaluation of fixed assets. 
Table 1: Structure of the population and sample companies

\begin{tabular}{|l|l|c|c|c|c|}
\hline SL. & \multicolumn{1}{|c|}{ Name of the Industry } & $\begin{array}{c}\text { Total } \\
\text { Company }\end{array}$ & $\begin{array}{c}\text { Company Year } \\
\text { Observations }\end{array}$ & $\begin{array}{c}\text { No of Sample } \\
\text { Companies }\end{array}$ & Percent \\
\hline 1. & Cement & 07 & 52 & 5 & 3.5 \\
\hline 2. & Ceramics Sector & 05 & 41 & 5 & 3.5 \\
\hline 3. & Engineering & 33 & 197 & 24 & 16.9 \\
\hline 4. & Food \& Allied & 18 & 125 & 16 & 11.3 \\
\hline 5. & Fuel \& Power & 18 & 119 & 14 & 9.9 \\
\hline 6. & Jute & 03 & 27 & 3 & 2.1 \\
\hline 7. & Miscellaneous & 12 & 77 & 10 & 7.0 \\
\hline 8. & Paper \& Printing & 02 & 11 & 1 & 0.7 \\
\hline 9. & Pharmaceuticals \& Chemicals & 28 & 188 & 24 & 16.9 \\
\hline 10. & Services \& Real Estate & 04 & 28 & 3 & 2.1 \\
\hline 11. & Tannery Industry & 05 & 36 & 4 & 2.8 \\
\hline 12. & Textile & 48 & 242 & 30 & 21.1 \\
\hline 13. & Travel \& Leisure & 04 & 18 & 3 & 2.1 \\
\hline & Total Companies & 187 & 1161 & 142 & 100.0 \\
\hline
\end{tabular}

\section{Methodology of the Study}

The study is mainly quantitative in approach and descriptive in nature. We have collected necessary data from secondary sources, especially from annual of the sample companies. Regulatory guidelines concerning FAR in Bangladesh have been gathered, such as IVS 2011, IAS 16, IAS 1, and BSEC guidelines regarding FAR. The study covered data available during the period 2007 to 2015 . A study period of nine years is considered adequate to measure the impact of FAR on financial numbers.

The study population includes all non-financial companies listed on the Dhaka Stock Exchange (DSE). The total number of companies listed on the DSE up to December 31, 2015, was 571 under 22 industry categories. We primarily classified companies into financial and nonfinancial categories. The population of the current study consists of all the 187 non-financial companies under 13 industries. We have excluded companies in the financial sector, such as banks, corporate bonds, debentures, financial institutions, insurance, mutual funds, and treasury bonds because of their different asset structures from those in non-financial companies. Besides, a study suggested that fair value accounting for financial institutions provides less relevant information (McInnis, Yu, \& Yust, 2018). We have excluded the IT sector because our primary investigation found no evidence of asset revaluation in this sector. Also, we have excluded companies in the telecom industry because of their extreme outlier values. Thus, the population of the study included all the remaining 187 listed companies, and the number of company year observations was 1,161 .
We again divided the non-financial companies into two categories, such as revaluers and non-revaluers. A revaluer is a company that has revalued its fixed assets during the study period. A company that has not done revaluation during the period under the study is a non-revaluer. We have excluded twelve companies because of the unavailability of annual reports and relevant data. Since at least three years' data needed for this study, we have again excluded 45 companies because of the unavailability of consecutive three years' data. Finally, the refined data set consists of 142 DSE listed non-financial companies. Data have been primarily collected and recorded with the help of MS Excel. After that, we have used SPSS software to analyze data through the application of statistical tools, such as descriptive statistics, percentage analysis, and the Mann-Whitney U test.

\section{Data Analysis and Results}

First, we have been calculated descriptive statistics, along with the growth of NAV, FAI, NPAT, NOCF, DER, and MBR for examining the existence of any financial number games played through applying the FAR model in Bangladesh. It helps understand the magnitude of the impacts of FAR on the selected variables. Finally, we have conducted the MannWhitney $\mathrm{U}$ test to identify whether the effects are statistically significant.

Table 2 shows the comparative descriptive statistics of the test variables for two separate periods, namely $t_{0}$ and $t_{1}$. Here, $t_{0}$ indicates values of test variables in the years before revaluation (for 52 revaluer companies) or the base 
year (for 90 non-revaluer companies). On the other hand, t1 indicates the corresponding values in the subsequent year.

The table reveals that the growth of NAV in non-revaluer companies was only about $4 \%$, which was 31 times higher in revaluer companies. There were no significant differences in mean, median, and standard deviation between the periods in non-revaluers companies. However, when we compare the years before and after revaluation, we found significant differences. We observe that companies with comparatively lower NAV achieved robust growth through FAR. Moreover, Table 3 shows that 4 out of 52 revaluers converted their negative NAV into large positive NAV through FAR. Thus, FAR has a profound positive effect on the NAV growth in Bangladesh. Negative shareholders' equity or NAV has different implications in different countries, such as delisting from stock exchanges, refusal of loan applications, and a negative image in the market. Thus, asset revaluation might be an attractive option for companies to avoid these consequences.

Regarding FAI, there was mostly no difference in the mean values between revaluers and non-revaluers in the base year $\left(t_{0}\right)$. In the subsequent year, both the groups witnessed positive growth, but the average was only around $4 \%$ in non-revaluers companies against the revaluers with an average of $50 \%$. The results are consistent with the predicted outcomes of this study that FAR significantly influences the FAI of corporate entities in Bangladesh. The increased intensity of fixed assets helps satisfy the requirements relating to mortgages and thus helps to borrow. However, considering data of only the revaluer companies, Table 4 shows that around 50\% of the revaluers increased their fixed assets by less than $99 \%$, the lowest growth of $9.5 \%$, and the highest growth of $14,603.8 \%$. About $10 \%$ of the revaluers increased their fixed assets by $900 \%$ and above. These growth percentages are significantly higher compared to the findings of Tay (2009), who found that about $50 \%$ of the sample firms increased their assets by less than $10 \%$, and the remaining firms increased their assets by more than $20 \%$ through FAR practices. Although the average increase in fixed assets through revaluation was $695.58 \%$, the accretion rate of the top ten revaluers, as shown in Table 5, indicated very significant changes in fixed assets' value caused by FAR.

The results concerning NPAT in Table 2 reveal significant differences in mean values. However, we observed that companies with lower profits are more inclined to practice FAR. The average NPAT increased in both the revaluers and non-revaluer companies, but the growth in revaluer companies was remarkable. We observed mixed findings concerning profit in the literature, where some studies found positive effects of FAR on profitability, whereas some others found either negative or no effect. The reason behind this high growth in NPAT may be the consequence of reduced borrowing costs, as supported by the debt covenant hypothesis.

Table 2 also reveals that the base year's average NOCF of revaluer companies was 101.43 million as compared to 501.44 million in non-revaluer companies. This outcome implies that companies with lower NOCF are more likely to have their assets revalued. In the subsequent year, when the NOCF decreased in revaluers companies, non-revaluers companies observed a significant growth. These findings are in line with the results of Lopes and Walker (2012) but contradict with Aboody et al. (1999) and Jamshidian and Sharifabadi (2016).

DER, as shown in Table 2, increased slightly by $8.54 \%$ in non-revaluer companies; in contrast, it decreased remarkably by $70.45 \%$ in revaluers companies. Such a result may be the consequence of high growth in equity capital caused by the FAR. Previous studies based on the debt covenant hypothesis support a reduction of the DER caused by the FAR practice. However, the magnitude of changes signifies that FAR is an instrument for playing financial numbers games.

It is evident from Table 2 that the MBR was higher in non-revaluer companies in t 0 . Interestingly, the situation changed drastically in the subsequent year, when nonrevaluers observed around $80 \%$ decreases in MBR, as compared to revaluers' $36.79 \%$. The fall in both groups may have caused by the long-lasting market crash in the country. Another reason might be the increased book value of the stock of revaluer companies due to the adjustment of the revalued asset price, which ultimately decreases MBR.

Since the skewness and kurtosis indicate that the data are not normally distributed, the Mann-Whitney U test is utilized to measure whether the differences in values between revaluers and non-revaluers are significant. The Mann-Whitney U test in Table 6 shows that there were significant differences between revaluers and nonrevaluers with respect to $\mathrm{NAVt}_{1}(\mathrm{U}=1482.000, \mathrm{p}=.000)$; FAIt $_{1}(\mathrm{U}=1281.500, \mathrm{p}=.000) ; \mathrm{NOCFt}_{0}(\mathrm{U}=1857.500$, $\mathrm{p}=.041) ; \mathrm{NOCFt}_{1}(\mathrm{U}=1688, \mathrm{p}=.006) ; \mathrm{DERt}_{0}(\mathrm{U}=$ $1554.500, \mathrm{p}=.009) ; \mathrm{DERt}_{1}(\mathrm{U}=1633.500, \mathrm{p}=.024)$; MBRt $_{0}(\mathrm{U}=1686.500, \mathrm{p}=.006) ; \mathrm{MBRt}_{1}(\mathrm{U}=1468.000$, $\mathrm{p}=.000$ ). All these indicate that the revaluation of fixed assets significantly influences the financial numbers concerning the test variable. Thus, the alternative hypothesis is accepted that there is a significant difference in NAV, NOCF, NPAT, DER, FAI, and MBR between the periods before and after the FAR. 
Table 2: Comparative descriptive statistics and growth of test variables

\begin{tabular}{|c|c|c|c|c|c|c|c|}
\hline \multirow{3}{*}{ Variable } & \multicolumn{5}{|c|}{ Descriptive Statistics } & \multirow{2}{*}{\multicolumn{2}{|c|}{$\begin{array}{l}\text { Growth in Mean Value } \\
{\left[\left\{\left(t_{1}-t_{0}\right) \div t_{0}\right\} \times 100\right]}\end{array}$}} \\
\hline & & \multicolumn{2}{|c|}{$t_{0}$} & \multicolumn{2}{|c|}{$t_{1}$} & & \\
\hline & & $\begin{array}{c}\text { Non- } \\
\text { Revaluer }\end{array}$ & Revaluer & $\begin{array}{l}\text { Non- } \\
\text { Revaluer }\end{array}$ & Revaluer & $\begin{array}{c}\text { Non- } \\
\text { Revaluer }\end{array}$ & Revaluer \\
\hline \multirow{5}{*}{ NAV } & Mean & 36.110 & 33.313 & 37.430 & 74.455 & $3.66 \%$ & $123.50 \%$ \\
\hline & Median & 22.700 & 18.200 & 23.100 & 44.900 & & \\
\hline & SD & 36.694 & 47.885 & 36.953 & 74.770 & & \\
\hline & Skewness & 1.546 & 3.157 & 1.243 & 1.938 & & \\
\hline & Kurtosis & 3.375 & 12.874 & 2.451 & 3.391 & & \\
\hline \multirow{5}{*}{ FAI } & Mean & 38.280 & 38.733 & 39.692 & 58.144 & $3.69 \%$ & $50.11 \%$ \\
\hline & Median & 36.200 & 39.990 & 38.645 & 59.875 & & \\
\hline & SD & 21.093 & 22.409 & 22.100 & 19.790 & & \\
\hline & Skewness & .334 & .141 & .208 & -.188 & & \\
\hline & Kurtosis & -.547 & -.598 & -.867 & -.595 & & \\
\hline \multirow{5}{*}{ NPAT } & Mean & 451.637 & 137.113 & 484.971 & 195.311 & $7.38 \%$ & $42.45 \%$ \\
\hline & Median & 132.550 & 42.950 & 96.600 & 45.750 & & \\
\hline & SD & 1077.904 & 293.086 & 1232.003 & 527.771 & & \\
\hline & Skewness & 6.147 & 3.829 & 5.926 & 4.512 & & \\
\hline & Kurtosis & 47.038 & 16.673 & 45.125 & 22.484 & & \\
\hline \multirow{5}{*}{ NOCF } & Mean & 501.442 & 101.434 & 810.647 & 84.103 & $61.66 \%$ & $(17.09 \%)$ \\
\hline & Median & 75.300 & 49.150 & 102.400 & 37.000 & & \\
\hline & SD & 1678.669 & 1282.295 & 2405.130 & 267.086 & & \\
\hline & Skewness & .048 & .980 & 5.053 & .585 & & \\
\hline & Kurtosis & 14.489 & 22.842 & 28.167 & 2.196 & & \\
\hline \multirow{5}{*}{ DER } & Mean & 1.370 & 2.376 & 1.487 & .702 & $8.54 \%$ & $(-70.45 \%)$ \\
\hline & Median & .860 & 1.660 & .890 & .540 & & \\
\hline & SD & 1.923 & 3.101 & 1.994 & 1.539 & & \\
\hline & Skewness & 2.554 & .824 & 2.615 & -3.181 & & \\
\hline & Kurtosis & 9.091 & 2.789 & 8.077 & 20.454 & & \\
\hline \multirow{5}{*}{ MBR } & Mean & 17.288 & 3.607 & 3.459 & 2.280 & $(79.99 \%)$ & $(36.79 \%)$ \\
\hline & Median & 3.605 & 2.330 & 2.605 & 1.350 & & \\
\hline & SD & 95.224 & 6.898 & 4.828 & 2.979 & & \\
\hline & Skewness & 8.459 & 3.218 & .961 & 2.793 & & \\
\hline & Kurtosis & 77.606 & 17.862 & 12.290 & 8.689 & & \\
\hline
\end{tabular}


Table 3: Companies that converted negative NAV into positive NAV through FAR

\begin{tabular}{|l|l|c|c|c|}
\hline S.L & \multicolumn{1}{|c|}{ Company } & NAV Before Revaluation & NAV after Revaluation & $\begin{array}{c}\text { Increase in NAV of BDT 10 } \\
\text { Par Value Share }\end{array}$ \\
\hline 1. & MEGCONMILK & -34.00 & 11.50 & 45.5 \\
\hline 2. & NORTHERN & -18.20 & 77.60 & 95.8 \\
\hline 3. & SONALIANSH & -4.70 & 222.50 & 227.2 \\
\hline 4. & PRIMETEX & -1.00 & 74.30 & 75.3 \\
\hline
\end{tabular}

Table 4: Growth of fixed assets by sample revaluers

\begin{tabular}{|c|c|c|}
\hline Growth Range of Fixed Assets & No. of Companies & Percentage of Revaluers \\
\hline Less than $100 \%$ [Lowest $9.5 \%$ ] & 24 & $46.15 \%$ \\
\hline $100 \%$ to less than $299 \%$ & 17 & $32.69 \%$ \\
\hline $300 \%$ to less than $899 \%$ & 06 & $11.54 \%$ \\
\hline \multirow[t]{2}{*}{$900 \%$ \& above [Highest $14,603.8 \%]$} & 05 & $09.62 \%$ \\
\hline & $N=52$ & $100.00 \%$ \\
\hline
\end{tabular}

Table 5: Top ten revaluers in terms of growth of fixed assets

\begin{tabular}{|l|c|c|c|c|}
\hline Company & $\begin{array}{c}\text { Year of } \\
\text { Revaluation }\end{array}$ & $\begin{array}{c}\text { Net fixed Asset before } \\
\text { Revaluation }\end{array}$ & $\begin{array}{c}\text { Revaluation Amount } \\
\text { (BDT in millions) }\end{array}$ & $\begin{array}{c}\text { Growth of Fixed Assets } \\
\text { through Revaluation (\%) }\end{array}$ \\
\hline ATLASBANG & 2011 & 26.0 & $3,797.0$ & $14,603.8$ \\
\hline NTLTUBES & 2011 & 50.7 & $5,325.6$ & $10,504.1$ \\
\hline EHL & 2013 & 152.7 & $4,197.1$ & $2,748.6$ \\
\hline GQBALLPEN & 2011 & 122.8 & $1,241.8$ & $1,011.2$ \\
\hline BDTHAI & 2007 & 88.1 & 867.0 & 984.1 \\
\hline LIBRAINFU & 2009 & 283.1 & $1,868.8$ & 660.1 \\
\hline MONNOCERA & 2011 & 316.8 & $1,817.7$ & 573.8 \\
\hline SONALIANSH & 2007 & 93.2 & 504.0 & 540.8 \\
\hline BSC & 2012 & 1212.8 & $4,470.5$ & 368.6 \\
\hline BANGAS & 2012 & 20.9 & 68.1 & 325.8 \\
\hline
\end{tabular}

Table 6: Test Statistics of the Mann-Whitney U Test

\begin{tabular}{|l|c|c|c|c|c|c|}
\hline & NAVt $_{0}$ & NAVt $_{1}$ & FAIt $_{0}$ & FAIt $_{1}$ & NPATt $_{0}$ & NPATt $_{1}$ \\
\hline Mann-Whitney U & 2072.000 & 1482.000 & 2293.000 & 1281.500 & 1888.500 & 2086.000 \\
\hline Wilcoxon W & 3450.000 & 5577.000 & 6388.000 & 5376.500 & 3266.500 & 3464.000 \\
\hline Z & -1.135 & -3.633 & -.199 & -4.482 & -1.912 & -1.076 \\
\hline Asymp. Sig. (2-tailed) & .256 & .000 & .842 & .000 & .056 & .282 \\
\hline & NOCFt $_{0}$ & NOCFt $_{1}$ & DERt $_{0}$ & DERt $_{1}$ & MBRt $_{0}$ & MBRt $_{1}$ \\
\hline Mann-Whitney U & 1857.500 & 1688.500 & 1554.500 & 1633.500 & 1686.500 & 1468.000 \\
\hline Wilcoxon W & 3235.500 & 3066.500 & 5382.500 & 2858.500 & 3064.500 & 2846.000 \\
\hline Z & -2.043 & -2.759 & -2.616 & -2.258 & -2.767 & -3.693 \\
\hline Asymp. Sig. (2-tailed) & .041 & .006 & .009 & .024 & .006 & .000 \\
\hline $\begin{array}{l}\text { a. Grouping Variable: } \\
\text { Revaluation Status }\end{array}$ & & & & & & \\
\hline
\end{tabular}




\section{Summary and Conclusion}

FAR is related to many different but interconnected dimensions of business, such as accounting, valuation, finance, and stock market operations. In Bangladesh, both upward and downward revaluations are allowed, but we could not find any instance of downward FAR in the country. This situation suggests there are some other games or motives for FAR other than representing the actual situation of fixed assets. The magnitude of changes in the selected variables caused by FAR indicates the existence of financial numbers game played by corporate managers in cooperation with the revaluer firms and the key players in the stock market.

A decrease in DER by $70 \%$ signifies that corporate management with high DER takes resort to FAR to increase their borrowing capacity, and thus arrange easy loans at lower costs. Along with the reduction of DER, high growth in NAV and FAI might help less profitable companies to make their stocks attractive to investors, and thus increase their stock prices. The increase in NPAT after revaluation also documented the signaling hypothesis. However, the study did not find any application of the Political cost hypothesis behind the FAR practice. Companies that revalue their fixed assets are, on average, less profitable than nonrevaluers, and more than half the revaluer companies were not in a position to produce operating cash flows positively before revaluation. Thus, companies with low profit and cash flows can increase their stock prices by disclosing FAR decisions. Moreover, our study of annual reports of revaluer companies found insufficient disclosure of asset revaluation by most companies, and the disclosures lack uniformity also. Altogether, the study concludes that fixed asset revaluation changes the image of a company's financial statements to a large extent, and thus creates a scope for playing financial numbers games.

Therefore, users of financial statements should be cautious in interpreting financial statements containing postrevaluation information and solicit more details. On the other hand, companies practicing the FAR model should furnish proper disclosures so that investors can make informed judgments. Accountable auditing practices and excellent corporate governance are needed to prohibit any evil motive behind the financial numbers game. The study findings will be interesting to a broad spectrum of corporate stakeholders having synergies with companies applying the FAR model. As the study has unveiled the profound impact of FAR, it can encourage companies in developing countries to practice the model. The findings of the present study may help regulators and professional bodies to understand the scope of the numbers game that can be played through FAR, which will help revamp their line role aimed at strengthening the bearish capital market and the accounting profession as well.
Like all other studies, this study has some limitations. The financial numbers game may not be limited to the items mentioned in this study. Besides, research may also be initiated and carried out by taking a sample of both financial and non-financial companies in the context of developing countries.

\section{References}

Abbas, S. K., Fazal, A., Ali, S. R., \& Faisal, N. (2019). Revaluation of fixed assets and future firm performance: evidence from cement sector of Pakistan. Journal of Computational and Theoretical Nanoscience, 16(5-6), 1-4.

Abdel-Khalik, A. R. (2010). Fair value accounting and stewardship. Accounting Perspectives, 9(4), 253-269.

Aboody, D., Barth, M. E., \& Kasznik, R. (1999). Revaluation of fixed assets and future firm performance: evidence from the UK. Journal of Accounting and Economics, 26(1-3), 147-171.

Alam, S. (2014). Applicability of revaluation model in Bangladesh: an empirical analysis. Jagannath University Journal of Business Studies, 4(1\&2), 77-93.

Alam, S. G. (2012). Recent trends in capital market of Bangladesh: critical evaluation of regulation. Khlong Nueng, Thailand: Asian Institute of Technology.

Azmi, A. F., \& Ali, S. (2019). Fixed assets revaluation and future firm performance: empirical evidence from Indonesia. The Indonesian Journal of Accounting Research, 22(3), 419-448.

Bae, J., Lee, J., \& Kim, E. (2019). Does fixed asset revaluation build trust between management and investors? Sustainability, 11(13), 3700. doi:10.3390/su11133700

Baek, H. Y., \& Lee, D. Y. (2016). Motives for and effects of asset revaluation: an examination of South Korean data. Emerging Markets Finance \& Trade, 52, 2808-2817.

Ballas, A., Panagiotoub, V., \& Tzovasc, C. (2014). Accounting choices for tangible assets: a study of Greek firms. SPOUDAI Journal of Economics and Business, 64(4), 18-38.

Barac, Z. A., \& Sodan, S. (2011). Motives for asset revaluation policy choice in Croatia. Croatian Operational Research Review, 2(1), 60-70.

Barlev, B., Fried, D., Hadda, J. R., \& Livna, J. (2007). Reevaluation of revaluations: a cross-country examination of the motives and effects on future performance. Journal of Business Finance \& Accounting, 34(7\&8), 1025-50.

Barth, M. E., \& Greg, C. (1998). Revalued financial, tangible, and intangible assets: associations with share prices and nonmarket-based value estimates. Journal of Accounting Research, 36, 199-233.

Brown, P., Izan, H. Y., \& Loh, A. L. (1992). Fixed asset revaluation and managerial incentives. Abacus, 28(1), 36-57.

BSEC. (2013). BSEC Guidelines for revaluation of assets. Dhaka, Bangladesh: Bangladesh Securities and Exchange Commission. 
Chainirun, P., \& Narktabtee, K. (2009). The evidence of management motivation to revalue property plant and equipment in Thailand. NIDA Business Journal, 5, 134-155.

Cheng, C. S., \& Lin, S. W. (2009). When do firms revalue their assets upwards? Evidence from the UK. International Journal of Accounting and Information Management, 17(2), 166-188.

Choi, T. H., Pae, J., Park, S., \& Song, Y. (2013). Asset revaluations: motives and choice of items to revalue. Asia-Pacific Journal of Accounting \& Economics, 20(2), 144-171.

Christensen, H. B., \& Nikolaev, V. V. (2013). Does fair value accounting for non-financial assets pass the market test? Review of Accounting Studies, 18(3), 734-75.

Cotter, J. (1999). Asset revaluations and debt contracting. Abacus, 35(3), 268-286.

Cotter, J., \& Zimmer, I. (2003). Disclosure versus recognition: the case of asset revaluations. Asia-Pacific Journal of Accounting \& Economics, 10(1), 81-99.

Damodaran, A. (2016). Damodaran on valuation: security analysis for investment and corporate finance. Hoboken, NJ: John Wiley \& Sons.

Dudycz, T., \& Praźników, J. (2020). Does the mark-to-model fair value measure make assets impairment noisy?: A literature review. Sustainability, 12(4), 1504. https://doi.org/10.3390/ su12041504

Easton, P. D., Eddey, P. H., \& Harris, T. S. (1993). An investigation of revaluation of tangible long-lived assets. Journal of Accounting Research, 31, 1-18.

Gaeremynck, A., \& Veugelers, R. (1999). The revaluation of assets as a signalling device: a theoretical and an empirical analysis. Accounting and Business Research, 29(2), 123-138.

Gaffikin, M. (2007). Accounting research and theory: the age of neo-empiricism. The Australasian Accounting Business \& Finance Journal, 1(1), 1-17.

Godfrey, J., Hodgson, A., \& Scott, H. (2000). Accounting theory (4th ed.). Singapore: Wiley.

Hasan, M. S., Rahman, R. A., \& Hossain, S. Z. (2014). Corporate accruals practices of listed companies in Bangladesh. European Journal of Economics and Management, 1(1), 17-46.

Herrmann, D., Saudagaran, S. M., \& Thomas, W. B. (2005). The quality of fair value measurement for property, plant and equipment. Accounting Forum, 30(1), 43-59.

Hitz, J.-M. (2007). The decision usefulness of fair value accounting-a theoretical perspective. European Accounting Review, 16(2), 323-362.

Hong, H. (2016). Information cascade and share market volatility: a Chinese perspective. Journal of Asian Finance, Economics and Business, 3(4), 17-24. https://doi.org/10.13106/jafeb.2016. vol3.no4.17

Hu, F., Percy, M., \& Yao, D. (2015). Asset revaluations and earnings management: Evidence from Australian companies. Corporate Ownership \& Control, 13(1), 1287-1296.
IAS. (2005). International accounting standard No. 16: Property, Plant, and Equipment. London, UK: International Accounting Standards Board.

Iatridis, G. E., \& Kilirgiotis, G. (2012). Incentives for fixed asset revaluations: the UK evidence. Journal of Applied Accounting Research, 13(1), 5-20.

Jaggi, B., \& Tusi, J. (2001). Management motivation and market assessment: revaluations of fixed assets. Journal of International Financial Management and Accounting, 12(2), 160-187.

Jamshidian, A., \& Sharifabadi, A. A. (2016). The relationship between fixed assets' revaluation and future performance of companies listed on Tehran stock exchange. International Business Management, 10(1), 5904-5915.

Jefriyanto, \& Mulya, H. (2019). Fixed asset revaluation: decision making. International Journal of Science and Research, 8(2), 433-439.

Kang, N. R., \& Paik, T.-Y. (2020). Who will take costs incurred by revaluation? The choice between two kinds of measurements. Academy of Accounting and Financial Studies Journal, 24(2), 1528-2635-24-2-524.

Khaled, K. I. (2011). Share market inquiry committee, 2011. Dhaka, Bangladesh: Ministry of Finance, The Peoples' Republic of Bangladesh.

Khalil, R., Asad, M., \& Khan, S. N. (2018). Management motives behind the revaluation of fixed assets for sustainability of entrepreneurial companies. International Journal of Entrepreneurship, 22(1S). [Online Journal] https://www. abacademies.org/articles/management-motives-behindthe-revaluation-of-fixed-assets-for-sustainability-ofentrepreneurial-companies-7635.html

Kothari, S. P., Shu, S., \& Wysocki, P. D. (2009). Do managers withhold bad news? Journal of Accounting Research, 47(1), 241-276.

Kovacs, D. M. (2013). The role and application of fair value accounting in the Hungarian regulatory framework. $\mathrm{PhD}$ Thesis, Corvinus University of Budapest, Budapest, Hungary.

Lee, J., Lee, S. J., Choi, S., \& Kim, S. (2020). The usefulness of other comprehensive income for predicting future earnings. Journal of Asian Finance, Economics, and Business, 7(5), 31-40. https://doi.org/10.13106/jafeb.2020.vol7.no5.031

Lin, Y. C., \& Peasnell, K. V. (2000). Fixed asset revaluation and equity depletion in the UK. Journal of Business Finance \& Accounting, 27(3\&4), 359-94.

Lopes, A. B., \& Walker, M. (2012). Asset revaluations, future firm performance and firm-level corporate governance arrangements: New evidence from Brazil. The British Accounting Review, 44(2), 53-67.

Madison, K. J. (2014). Agency theory and stewardship theory integrated, expanded, and bounded by context: an empirical investigation of structure, behavior, and performance within family firms. PhD Thesis, University of Tennessee, Knoxville, Tennessee, USA. 
Majercakova, D., \& Skoda, M. (2015). Fair value in financial statements after financial crisis. Journal of Applied Accounting Research, 16(3), 312-332.

McInnis, J. M., Yu, Y., \& Yust, C. G. (2018). Does fair value accounting provide more useful financial statements than current GAAP for banks? The Accounting Review, 93(6), 257-279.

Missonier-Piera, F. (2007). Motives for fixed-asset revaluation: an empirical analysis with Swiss data. The International Journal of Accounting, 42(2), 186-205.

Mohammadrezaei, F., Mohd-Saleh, N., \& Banimahd, B. (2015). The effects of mandatory IFRS adoption: a review of evidence based on accounting standard setting criteria. International Journal of Disclosure and Governance, 12(1), 29-77.

Mulford, C. W., \& Comiskey, E. E. (2005). The financial numbers game: detecting creative accounting practices. Hoboken, NJ: John Wiley \& Sons.

Nguyen, D. D., \& Nguyen, C. V. (2020). The impact of operating cash flow in decision-making of individual investors in Vietnam's stock market. Journal of Asian Finance, Economics and Business, 7(5), 19-29. https://doi.org/10.13106/jafeb.2020. vol7.no5.019

Nijam, H. M. (2018). Motives for reporting fixed assets at revalued amount: evidence from a developing economy. Global Business Review, 19(3), 604-622.

Pae, J., Park, S., \& Song, Y. (2010). Asset revaluations to tide over financial difficulties: a case study of S company. Korean Accounting Journal, 19(3), 201-220.

Palea, V. (2014). Fair value accounting and its usefulness to financial statement users. Journal of Financial Reporting and Accounting, 12(2), 102-116.

Penman, S. H. (2007). Financial reporting quality: is fair value a plus or a minus? Accounting and Business Research, 37(Sup1), 33-44.

Poerwati, R. T., Hardiningsih, P., Srimindarti, C., \& Sundari, R. I. (2020). Does the company's scale, fixed asset intensity and operating cash flow affect asset revaluation? Jurnal Analisis Bisnis Ekonomi, 18(1), 1-13.

Rafay, A., Yasser, F., \& Khalid, Z. (2019). Revaluation of noncurrent assets under IAS-16: possibility of any managerial inducement: evidence from a South Asian economy 93-105. DLSU Business \& Economics Review, 29(1), 93-105.

Rahman, M. T. (2017). Revaluation of fixed assets before IPO: a study on textile industry in Bangladesh. Journal of Finance and Accounting, 5(5), 200-205.

Rahman, M. T., Hossain, S. Z., \& Habibullah, M. (2017). Stock market crash in Bangladesh: the moneymaking psychology of domestic investors. American Journal of Theoretical and Applied Business, 3(3), 43-53.

Rahman, M. T., Hossain, S. Z., \& Omar, N. (2017). Factors influencing subscription of IPO in Bangladesh. International Journal of Economics, Management and Accounting, 25(3), 529-548.

Ronen, J. (2008). To fair value or not to fair value: a broader perspective. Abacus, 44(2), 181-208.

Sayce, S., \& Connellan, O. (2002). From existing use to value in use: time for a paradigm shift? Property Management, 20(4), 228-251.

Sellhorn, T., \& Stie, C. (2019). Fair value measurement for longlived operating assets: research evidence. European Accounting Review, 28(3), 573-603.

Seng, D., \& Su, J. (2011). Asset devaluations: the motivation behind management decisions evidence from New Zealand firms. International Journal of Business Strategy, 11(2), 67-76.

Song, Y., \& Pae, J. (2019). The impact of appraisal quality on the voluntary disclosure of asset revaluation. Asia-Pacific Journal of Financial Studies, 48(5), 615-639.

Tabari, N. Y., \& Adi, M. (2014). Factors affecting the decision to revaluation of assets in listed companies of Tehran stock exchange(TSE). International Journal of Scientific Management and Development, 2(8), 373-377.

Tay, I. (2009). Fixed asset revaluation: management incentives and market reactions. Master's Thesis, Lincoln University. Chester County, Pennsylvania, USA.

Wali, S. (2015). Mechanisms of corporate governance and fixed asset revaluation. International Journal of Accounting and Finance, 5(1), 82-97.

Wang, Z. (2006). Upward revaluation of fixed assets. Journal of Business \& Economics Research, 4(1), 53-58.

Whittered, G., \& Chan, Y. K. (1992). Asset revaluations and the mitigation of underinvestment. Abacus, 28(1), 58-74.

Yao, D. F., Percy, M., \& Hu, F. (2015). Fair value accounting for non-current assets and audit fees: evidence from Australian companies. Journal of Contemporary Accounting \& Economics, 11(1), 31-45.

Yoo, C. Y., Choi, T. H., \& Pae, J. (2018). The case of the asset revaluation boom in Korea during the global financial crisis. Journal of Business Finance \& Accounting, 45(1-2), 92-114.

Zakaria, A., Edwards, D. J., Holt, G. D., \& Ramchandran, V. (2014). A review of property, plant and equipment asset revaluation decision making in Indonesia: development of a conceptual model. Mindanao Journal of Science and Technology, 12, 109-128. 